ISSN: $1679-3013$

\title{
POPULATIONAL DYNAMICS OF Pseudodiaptomus marshi (CRUSTACEA: COPEPODA) IN THE CAETÉ ESTUARY (BRAZIL)
}

\author{
André MAGALHÃES ${ }^{1}$ \\ Luci Cajueiro Carneiro PEREIRA ${ }^{2}$ \\ Marcilenia de Jesus Silva RIBEIRO \\ Tsui-Hua LIANG ${ }^{1}$ \\ Rauquírio Marinho da COSTA ${ }^{1, *}$
}

\begin{abstract}
The aim of this study was to evaluate the spatial and temporal density and biomass distribution of the planktonic copepod Pseudodiaptomus marshi in the Caeté Estuary (Pará, Brazil) during the months of June and December of 1998 (dry season), February and May of 1999 (rainy season). The Caeté Estuary was characterized by high spatial and temporal variations in salinity $(0.7 \pm 0.55$ to $37.2 \pm 0.21)$. The Spearman correlation analysis showed a significant negative correlation ( $r s=-0.75, p<0.05$ ) between salinity and density of $P$. marshi, suggesting the species preference for estuarine areas where oligohaline-mesohaline regimes were predominant. A linear length-weight relationship was obtained and expressed as: $D W=125.46+0.1467 \mathrm{PL}(r$ $=0.32 ; \mathrm{p}<0.05)$. In the present study, density and biomass values oscillated between 0.0 to $21.4 \pm 18.26$ ind $\mathrm{m}^{-3}$ and 0.0 to $0.583 \pm 0.51 \mathrm{mg} \mathrm{DW} . \mathrm{m}^{-3}$, respectively. There, monthly differences in density $(H=6.71 ; p<0.05)$ and biomass $(H=6.76 ; p<0.05)$ among the three sampling areas were significant only in June, with the highest values registered in the upper estuary. The results showed that spatial and seasonal variability registered in the occurrence and distribution of $P$. marshi was strongly regulated by salinity, with the highest density and biomass recorded concomitantly to the lowest salinity values.
\end{abstract}

Key-words: Biomass, copepod, salinity, Amazon estuary.

\section{RESUMO}

\section{DINÂMICA POPULACIONAL DE Pseudodiaptomus marshi (CRUSTACEA: COPEPODA) NO ESTUÁRIO DO CAETÉ (BRASIL)}

O presente estudo tem por objetivo principal avaliar a distribuição espacial e temporal da densidade e biomassa do copépodo planctônico Pseudodiaptomus marshi no Estuário do Caeté (Pará, Brasil), durante os meses de junho e dezembro de 1998 (estação seca), fevereiro e maio de 1999 (estação chuvosa). O Estuário do Caeté caracterizou-se por uma ampla variação espacial e temporal da salinidade $(0,7 \pm 0,55$ a $37,2 \pm 0,21)$. A análise de correlação de Spearman revelou uma correlação negativa significativa ( $r s=-0,75 ; \mathrm{p}<0,05$ ) entre a salinidade e a densidade de $P$. marshi, sugerindo a preferência desta espécie por áreas estuarinas onde foram dominantes os regimes oligohalino-mesohalino. A relação peso-comprimento foi do tipo linear, sendo expressa pela equação: $P S=125,46+0,1467 C P(r=0,32 ; p<0,05)$. No presente estudo, os valores de densidade e biomassa variaram respectivamente de 0,0 a $21,4 \pm 18,26$ ind. $\mathrm{m}^{-3}$ e 0,0 a $0,583 \pm 0,51 \mathrm{mg}$ PS. $\mathrm{m}^{-3}$. As diferenças mensais na densidade $(H=6,71 ; p<0,05)$ e biomassa $(H=6,76 ; p<0,05)$ entre as três áreas de amostragem foram significativas somente em junho, com os maiores valores registrados no estuário interno. Os resultados revelaram que a variabilidade espacial e sazonal na ocorrência e distribuição de $P$. marshi foi fortemente regulada pela salinidade, com as maiores densidades e biomassas registradas simultaneamente aos menores valores de salinidade.

Palavras-chave: Biomassa, copépodo, salinidade, estuário amazônico.

Contatos: ${ }^{1}$ Laboratório de Plâncton e Cultivo de Microalgas, ${ }^{2}$ Laboratório de Oceanografia Costeira e Estuarina, Universidade Federal do Pará, Instituto de Estudos Costeiros. Alameda Leandro Ribeiro, s/n, Aldeia, 68600-000, Bragança, PA, Brazil. ${ }^{*}$ Corresponding author: Tel.: +55 91 34254536; fax: +55 9134251593 . 


\section{INTRODUCTION}

With regard to the organisms that comprise the zooplankton of coastal and marine environments, copepods are one of the most important in terms of density and biomass (Froneman 2002, Kibirige \& Perissinotto 2003). In these environments, copepods are among the mainly secondary producers (Islam et al. 2006), playing a relevant role in nutrient recycling and in the transfer of energy between phytoplankton and bacterioplankton to the highest trophic levels (Parsons et al. 1984, Banse, 1995). Furthermore, they are well known as a natural food source for fish larvae (Schipp et al. 1999).

The variability observed in composition, distribution, density and biomass of estuarine copepods is spatially and temporally heterogeneous. In mangrove estuaries, this variability is due to environmental parameters such as salinity, turbidity, tidal regime, local pluviometric patterns, food availability, etc. (Revis 1988, Mckinnon \& Klumpp 1998, Ara 2004, Osore et al. 2003).

The calanoid copepods of the genus Pseudodiaptomus inhabit fresh to hypersaline waters and are widely distributed around the world (Walter 1986). Pseudodiaptomus marshi Wright, 1936 is observed along the western coast of the Central and South Atlantic (Almeida Prado Por \& Lansac-Tôha 1984, Walter 1989, Reid 1990, Artigas et al. 2003, Suárez-Morales 2003). In Brazil, this species has often been reported as an important component of the mesozooplankton communities in many estuaries and tidal creeks from the North (Peres 1999, Krumme \& Liang 2004) and Northeast regions (Bonecker 1995, Silva et al. 1996). In the Caeté Estuary, some studies on zooplankton such as Barletta-Bergan et al. (2002), who evaluated structure and seasonal dynamics of larval fish assemblage and Magalhães et al. (2006) which studied spatial and temporal variations of two Pseudodiaptomus species, observed that the variability in density and biomass distribution of those groups were associated with seasonal periods, as well as with sampling sites. Therefore, in order to better understand the dynamics of these organisms in Amazonian estuaries, the present study aimed to know the spatial and temporal distribution patterns, in terms of density and biomass, of the planktonic copepod $P$. marshi regarding the salinity gradient in the Caeté Estuary.

\section{MATERIAL AND METHODS}

\section{Study area}

This study was performed in the Caeté Estuary $\left(0^{\circ} 45^{\prime}-1^{\circ} 07^{\prime} \mathrm{S}\right.$ e $\left.46^{\circ} 50^{\prime}-46^{\circ} 30^{\prime} \mathrm{W}\right)$ located on the Northern Brazilian littoral (Figure 1 ). The climate is equatorial warm and humid. Mean annual pluviometric precipitation is approximately 2,500 $\mathrm{mm}$ with most precipitation occurring in the rainy season (January at May) (INMET 2003) (Figure 2). The Caeté Estuary is influenced by a semidiurnal macro-tide regimen with tidal heights greater than $5 \mathrm{~m}$ (Diele 2000). This ecosystem is bordered by mangrove forests, composed of $20 \mathrm{~m}$ tall trees (Lara \& Dittmar 1999), dominated by Rhizophora mangle Linnaeus, 1753, Avicennia germinans Linnaeus, 1764 and Laguncularia racemosa Linnaeus, 1807 (Menezes et al. 2003). A detailed description of the study area can be found in Diele et al. (2005). The studied area was divided in three sampling sites, according to the salinity gradient: upper (A), middle (B) and lower estuary (C) (Figure $1)$. The lower estuary is strongly influenced by seawater. The opposite is verified to the upper estuary, which is directly affected by Caeté River discharges. In the middle estuary, intermediate salinity values can be observed. 
MAGALHÃES et. al. Populational dynamics of Pseudodiaptomus marshi (Crustacea: Copepoda) in the Caeté estuary (Brazil)

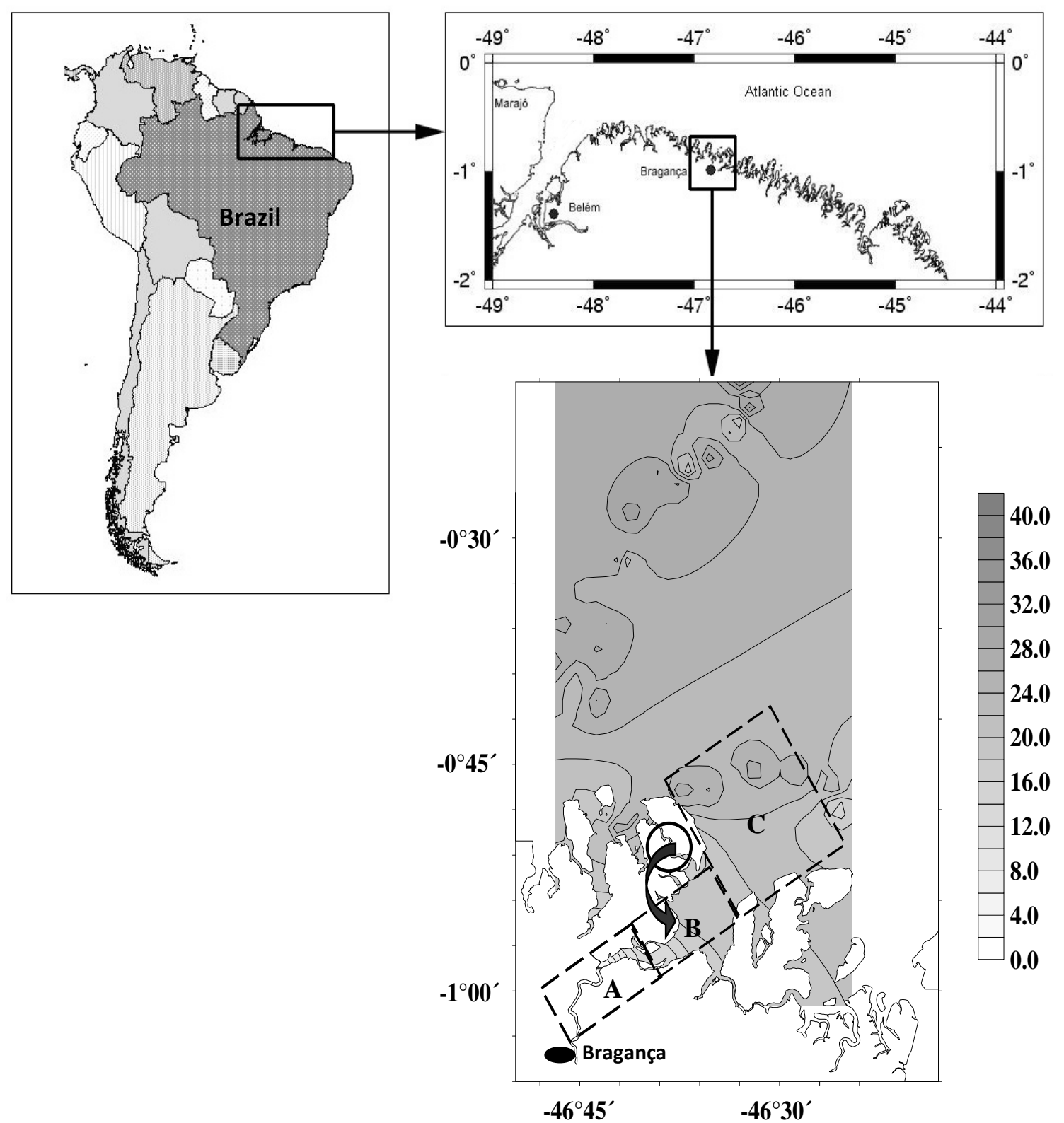

Figure 1 - Geographical localization of the Caeté Estuary and position of the three sampling areas, determined according the salinity gradient: upper $(A)$, middle $(B)$ and lower estuary $(C)$. The circled area in the map was considered part of the middle estuary.

\section{Field methods}

For each sampling area three replicates were obtained downstream during spring tide, producing a total of 36 plankton samples. These samplings were carried out during the months of June and December of 1998 (dry season), February and May of 1999 (rainy season).

Zooplankton samples were collected by sub-surface hauls with duration of 5 minutes, using a conical plankton net $(300 \mu \mathrm{m}$ mesh size and $0.32 \mathrm{~m}$ mouth opening diameter) equipped with a digital flowmeter (Hydrobios, Kiel) attached to the mouth of the net. The hauls were performed using a small powerboat at an average speed of 1.5 knots. After collection, samples were immediately preserved in a $4 \%$ buffered formalinseawater solution. Sub-surface salinity measurements were registered in situ during all sampling procedures using an optical refractometer (Atago, Model S/Mill-E). 


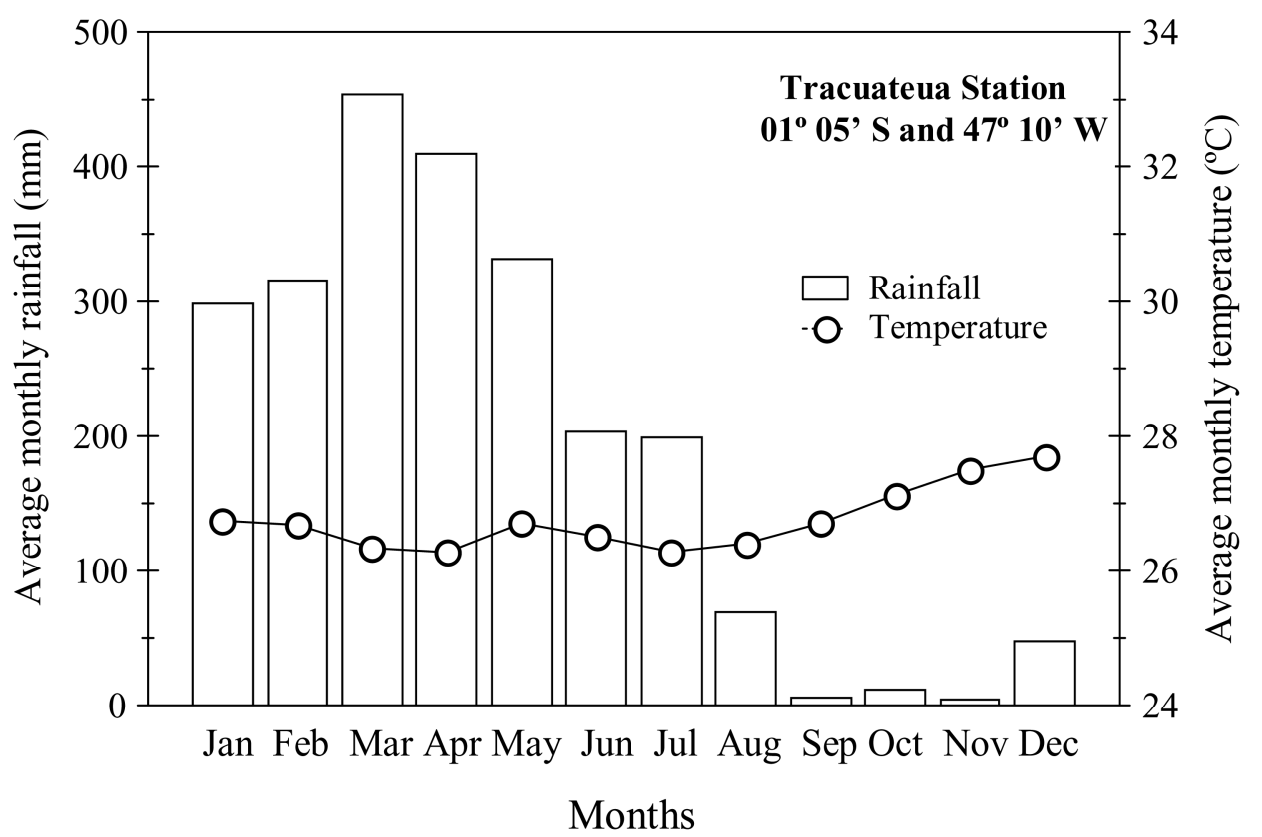

Figure 2 - Climate diagram of Tracuateua Meteorological Station. Average monthly between 1995 and 2002 (Source: INMET, 2003).

\section{Laboratory procedures}

Subsamples were obtained to determine numerical density and biomass using a Folsom plankton sample splitter (Mcewen et al. 1957), as described by Boltovskoy (1981). The frequency of occurrence (percentage of samples in which $P$. marshi occurred in relation to the total number of samples) was also determined. In the present study, only the adult stage of $P$. marshi (CVI) was investigated. The length of the specimens (prosome length) was measured through an eyepiece micrometer with the animals placed in a lateral position to avoid possible errors that could be triggered by the body curvature. After measurement, the organisms were quickly rinsed in distilled water and placed in minuscule (40 $\mathrm{mm}$ in diameter), pre-weighed, aluminum foil dishes. After, they were dried at a constant temperature $\left(60^{\circ} \mathrm{C}\right)$ in an electric oven for 24 hours and put in a desiccator with silica gel to cool at room temperature. Their dry weight measurements were taken using an electronic microbalance (Sartorius, Model BP-410S). Weight loss subsequent to formalin use was not taken into consideration (Chisholm \& Roff 1990).

Biomass was estimated by the product of density (ind. $\mathrm{m}^{-3}$ ) of each length class and the average dry weight of individuals sampled in each class (DW, $\mu \mathrm{g}$ ), which was calculated from prosome length $(P L, \mu \mathrm{m})$, by a linear length-weight regression equation, expressed as:

$$
\mathrm{DW}=a+b \mathrm{PL}
$$

Where $a$ and $b$ are constant.

\section{Data analysis}

The raw data of density and biomass were log-transformed $\log (n+1)$ so that their distributions approached normality. If data remained non-normal, even after transformation, a Kruskal-Wallis non-parametric test was applied to evaluate the differences in density and biomass of $P$. marshi in spatial and temporal scale (Zar 1999). Correlation between density of $P$. marshi species and salinity were assessed using the Spearman rank correlation analysis. The analyses were performed with the computer software package STATISTICA, version 5.0. 
MAGALHÃES et. al. Populational dynamics of Pseudodiaptomus marshi (Crustacea: Copepoda) in the Caeté estuary (Brazil)

\section{RESULTS AND DISCUSSION}

In the Caeté Estuary, a large variation of salinity was observed $(0.7 \pm 0.55$ to $37.2 \pm 0.21$; average \pm standard deviation). Independently from seasonal sampling period, the upper estuary always presented the lowest average salinity values, with a gradual downstream increase. An opposite trend was verified for the lower estuary (Figure 3). Similar observations were registered by Barletta et al. (2005). Significant differences between the three sampling areas were only reported in the month of May $(p<0.05)$. The relatively high salinity $(28.8)$, observed in the upper estuary in February may be due to the inundation of mangrove areas which remained exposed during the dry season, when salt crystal formations could be observed. During months of relatively high precipitation, the strong river flow leads to flooding in these areas, occasioning the increase of salinity in punctual zones of the estuary, which could explain the absence of $P$. marshi in the samples collected during this month.

In this survey, seasonal changes in salinity could be clearly noted, mainly when comparing data recorded in the upper estuary in May (rainy season) with those observed in December (dry season). This probably occurred due to differences in the amount of rainfall between the two seasons.

Although $P$. marshi is able to survive and even reproduce in hypersaline waters (Medeiros et al. 2006), the significant negative Spearman correlation ( $r s=-0.75$; $\mathrm{p}<0.05$ ) between salinity and density suggests the species preference for estuarine areas where oligohaline-mesohaline regimes were predominant, as already reported for other estuaries of the Brazilian coast (Nascimento \& Rocha 1984, Araujo 1996). Thus, the low intraspecific tolerance to high salinities was responsible by absence of $P$. marshi in the samples collected in different sampling areas, as well as in different seasonal periods (Figure 3). Madhu et al. (2007) showed that seasonal oscillations in salinity represent a major factor controlling the distribution and abundance of micro- and mesozooplankton in a tropical estuary (Cochin backwaters - India). In the present study, along with the decrease in the rainfall during the dry season, a gradual decrease in the river discharge is observed and a consequent increase in salinity throughout the estuary was registered. The rainfall influence on seasonal changes in salinity has been reported in several tropical estuaries worldwide (Habib Mohamed \& Abdul Rahaman 1987, Thüllen \& Berger 2000, Blaber 2002, Lam-Hoai et al. 2006, Giarrizzo \& Saint-Paul 2008).

P. marshi was present in only $27.8 \%$ of the thirty-six samples, and it was not observed in any of the three sampling areas during the month of February, besides being absent in lower estuary during June and December. Although this organism is characterized as a numerous species in northern and northeastern Brazilian estuaries (Björnberg 1981), in the Caeté Estuary P. marshi showed low density values that ranged from 0.0 to $21.4 \pm 18.26$ ind. $\mathrm{m}^{-3}$ (Figure 3 ). Monthly differences in density among sampling areas (spatial study) were significant only in June $(H=6.71 ; p<0.05)$, with the highest values registered in the upper estuary. However, there were no significant differences between density registered within a same area, but in different months (temporal study).

Once several species of zooplanktophagous fish (e.g. Stellifer rastrifer Jordan 1889, Stellifer naso Jordan 1889, Macrodon ancylodon Bloch \& Schneider 1801) feed preferentially on copepods, among them juveniles and adults of $P$. marshi (Keuthen 1998, Camargo \& Isaac 2004), the biomass assessment through length-weight equations could be also useful to evaluate copepod contribution in the diet of these fish, and so better understand their role in the local aquatic food webs. In the present study, a significant linear relationship between dry weight and prosome length was obtained for $P$. marshi and described as: $\mathrm{DW}=125.46+0.1467 \mathrm{PL}(r=0.32 ; \mathrm{p}<0.05)$. This relationship was based on measurements from individuals collected in different sampling seasons. Therefore, it is assumed that possible seasonal variations in length-weight relationship of P. marshi had been buffered. According to Ara (2001), such variations cannot be 
significant as variations in temperature and food availability in tropical and sub-tropical regions are much less significant than in temperate and boreal areas.
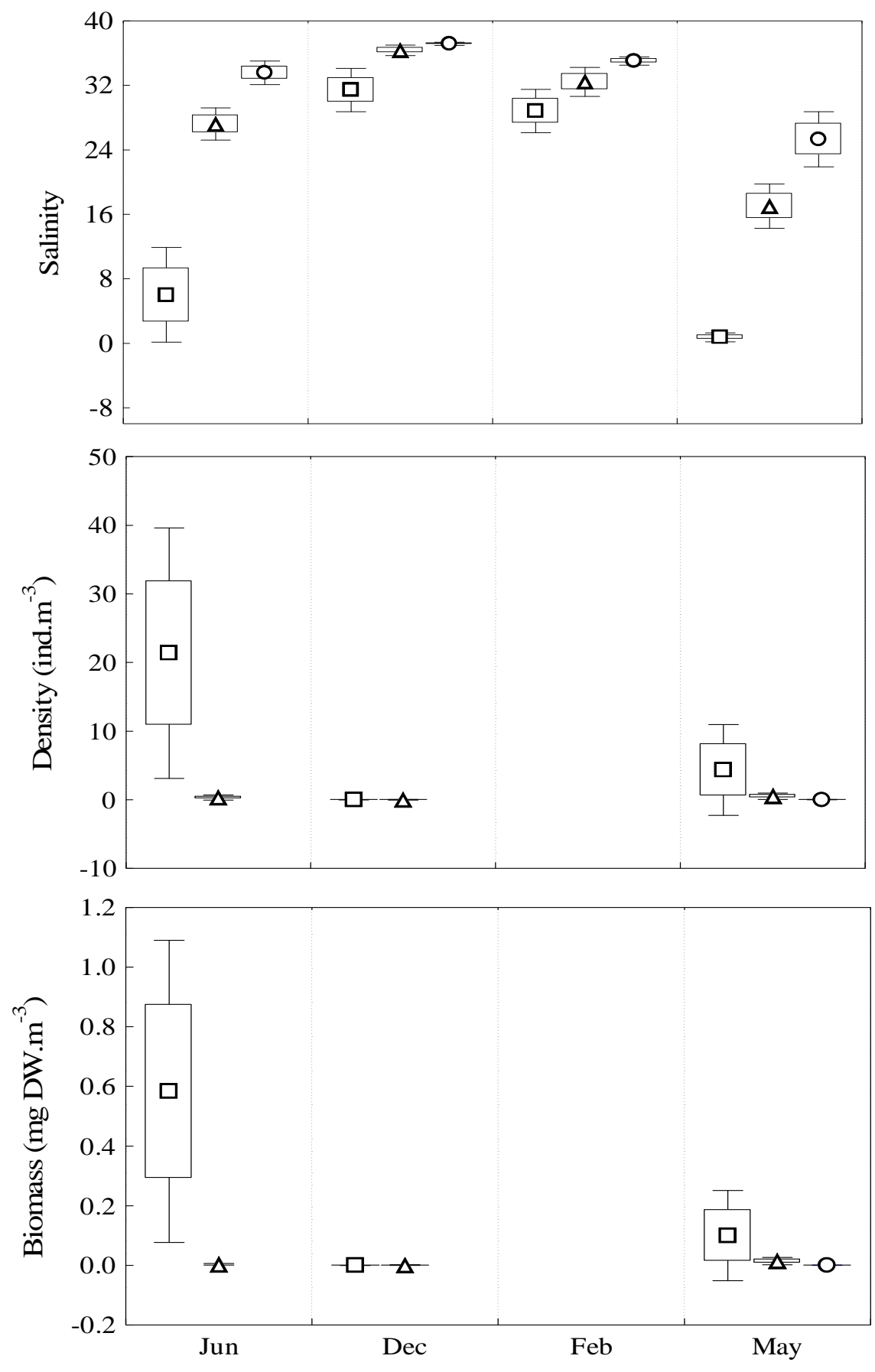

Figure 3 - Spatial and temporal variation in salinity, density and biomass values of $P$. marshi in the Caeté Estuary ( $\square$ upper, $\Delta$ middle and $\circ$ lower estuary). These values are expressed as mean \pm standard deviations (vertical bars) and standard errors (box).

Information regarding the estuarine copepods biomass (dry weight), in special $P$. marshi, is still scarce. Due to the large mesh size of the plankton net employed in this survey, the overall biomass estimations were performed exclusively for the adult stages. Adult dominance, in the case of Pseudodiaptomus genus specimens, was previously reported (Uye et al. 1983, Uye \& Sano 1995). Biomasses obtained in this study oscillated 
MAGALHÃES et. al. Populational dynamics of Pseudodiaptomus marshi (Crustacea: Copepoda) in the Caeté estuary (Brazil)

between 0.0 to $0.583 \pm 0.51 \mathrm{mg} \mathrm{DW} . \mathrm{m}^{-3}$ (Figure 3 ). Similarly as observed for density, monthly differences in biomass between sampling areas were significant only in June $(\mathrm{H}$ $=6.76 ; \mathrm{p}<0.05)$, while differences recorded within the same area, but in different months, were significant only for the upper estuary $(H=8.19 ; p<0.05)$.

In the Caeté Estuary, density values of $P$. marshi were lower than those reported in other Brazilian estuaries (Silva et al. 2003, Lucas 2006). The low values registered in the studied area may have occurred due to the characteristic of the net mesh $(300 \mu \mathrm{m})$ employed in the plankton samplings that captured predominantly adult individuals (CVI). Consequently, naupliar and copepodits stages that could have influenced the overall population density and biomass were not taken into consideration. In conclusion, the present data are useful to understand the population structure of $P$. marshi planktonic copepod in the Caeté Estuary, although future ecological studies should be also carried out on a short and long-time scale, with the employment of not only $300 \mu \mathrm{m}$, but also 64 and $120 \mu \mathrm{m}$ mesh size nets, in order to capture the early development stages (nauplii) as well as juveniles (copepodits).

\section{CONCLUSIONS}

The Caeté River Estuary was characterized by an accentuated variation in surface water salinity, which influenced spatial and temporal occurrence and distribution of $P$. marshi. The significant negative Spearman correlation between salinity and density suggests the species preference for estuarine areas where oligohaline-mesohaline regimes were predominant. Therefore, a low intraspecific tolerance to high salinities was responsible by absence of $P$. marshi in the samples collected in different sampling areas, as well as in different seasonal periods, as was evidenced during the months of June, December and February. A linear length-weight regression equation was determined and the dry weight for $P$. marshi assessed using this equation. The relatively low density and biomass values reported in the Caeté Estuary could be explained by the selectivity of the net used in this study that captured predominantly adult individuals.

\section{ACKNOWLEDGMENTS}

This study was carried out as part of the Brazilian-German Cooperative Project, MADAM, and was financed by the "Conselho Nacional de Desenvolvimento Científico e Tecnológico (CNPq)" and the German Ministry for Education and Research (BMBF) under the code 03F0154A. This is MADAM-Contribution No 121. Thanks to Victoria Isaac and Dr. Dirk Schories for their helpful assistance. The first author is grateful to the "Coordenação de Aperfeiçoamento de Pessoal de Nível Superior (CAPES)" for the scholarship support. Financial support was also provided by the Laboratório de Plâncton e Cultivo de Microalgas da Universidade Federal do Pará (UFPA). Finally, the authors Costa, R. and Pereira, L. thanks CNPq (Brazil) for their productivity research grants (308953/2006-1 and 304392/2005-7, respectively).

\section{REFERENCES}

ALMEIDA PRADO POR, M.S.; LANSAC-TÔHA, F.A. Distribution of brackish water Calanoida (Copepoda) along the coasts of Brazil. Hydrobiologia, v. 113, p. 147-150, 1984.

ARA, K. Length-weight relationships and chemical content of the planktonic copepods in the Cananéia Lagoon estuarine system, São Paulo, Brazil. Plankton Biology \& Ecology, v. 48, p. 121-127, 2001.

ARA, K. Temporal Variability and Production of the Planktonic Copepod Community in the Cananéia Lagoon Estuarine System, São Paulo, Brazil. Zoological Studies, v. 43, n. 2, p. 179-186, 2004.

ARTIGAS, L.F.; VENDEVILLE, P.; LEOPOLD, M.; GUIRAL, D.; TERNON, J.-F. Marine biodiversity in French Guiana: Estuarine, coastal, and shelf ecosystems under de influence of Amazonian waters. Gayana, v. 67, n. 2, p. 302-326, 2003. 
ARAUJO, H.M.P. Zooplâncton do Estuário dos rios Piauí e Fundo (Sergipe, Brasil): flutuações espaciais, sazonais e tidais. Curitiba, 1996. 193f. Tese (Doutorado em Zoologia). Universidade Federal do Paraná.

BANSE, K.I. Biomass and production measurements - Zooplankton: pivotal role in the control of ocean production. ICES Journal of Marine Science, v. 52, p. 265-277, 1995.

BARLETTA-BERGAN, A.; BARLETTA, M.; SAINT-PAUL, U. Structure and seasonal dynamics of larval fish in the Caeté river estuary in North Brazil. Estuarine, Coastal and Shelf Science, v. 54, p. 193-206, 2002.

BARLETTA, M.; BARLETTA-BERGAN, A.; SAINT-PAUL, U.; HUBOLD, G. The role of salinity in structuring the fish assemblages in a tropical estuary. Journal of Fish Biology, v. 66, p. 45-72, 2005.

BJÖRNBERG, T.K.S. Copepoda. In: BOLTOVSKOY, D. (Ed.). Atlas del Zooplancton del Atlantico Sudoccidental y Métodos de Trabajo con Zooplancton Marino. Mar del Plata: Instituto Nacional de Investigación y Desarrollo Pesquero (INIDEP), 1981, p. 587 - 679.

BLABER, S.J.M. Fish in hot water: the challenges facing fish and fisheries research in tropical estuaries. Journal of Fish Biology, v. 61 (Suppl. A), p. 1-20, 2002.

BOLTOVSKOY, D. (Ed.). Atlas del Zooplancton del Atlantico Sudoccidental y Métodos de Trabajo con Zooplancton Marino. Mar del Plata: Instituto Nacional de Investigación y Desarrollo Pesquero (INIDEP), 1981. 936 p.

BONECKER, S.L.C. Dinâmica do zooplâncton no sistema estuarino do Rio Mucuri (BA). São Paulo, 1995. 154f. Dissertação (Mestrado em Zoologia) - Departamento de Zoologia. Universidade de São Paulo.

CAMARGO, M.; ISAAC, V. Food categories reconstruction and feeding consumption estimates for the Sciaenid Macrodon ancylodon (Bloch \& Schneider), and the congeneric fishes Stellifer rastrifer (Jordan) and Stellifer naso (Jordan) (Pisces, Perciformes) in the Caeté Estuary, Northern Coast of Brazil. Revista Brasileira de Zoologia, v. 21, n.1, p. 85-89, 2004.

CHISHOLM, L.A.; ROFF, J.C. Size-weight relationships and biomass of tropical neritic copepods. Marine Biology, v. 106, p. 71-77, 1990.

DIELE, K. Life history and population structure of the exploited mangrove crab Ucides cordatus cordatus (Linnaeus, 1763) (Decapoda: Brachyura) in the Caeté estuary, North Brazil. Bremen, 2000. 103f. Tese (Doutorado em Ciências Naturais). Universidade de Bremen.

DIELE, K.; KOCH, V.; SAINT-PAUL, U. Population structure, catch composition and CPUE of the artisanally harvested mangrove crab Ucides cordatus (Ocypodidae) in the Caeté estuary, North Brazil: Indications for overfishing? Aquatic Living Resources, v. 18, p. 169-178, 2005.

FRONEMAN, P.W. Response of the biology to three different hydrological phases in the temporarily open/closed Kariega estuary. Estuarine, Coastal and Shelf Science, v. 55, p. 535-546, 2002.

GIARRIZZO, T.; SAINT-PAUL, U. Ontogenetic and seasonal shifts in the diet of the pemecou sea catfish Sciades herzbergii (Siluriformes: Ariidae), from a macrotidal mangrove creek in the Curuçá estuary, Northern Brazil. Revista de Biología Tropical, v. 56, n. 2, p. 861-873, 2008.

HABIB MOHAMED, T.A.M.; ABDUL RAHAMAN, A. Seasonal distribution of Plankton in Agniar estuary. Journal of the Marine Biological Association of India, v. 29, n. 1-2, p. 273-279, 1987.

INSTITUTO NACIONAL DE METEOROLOGIA (INMET). Normas climatológicas (19952002). Brasilia (DF): Instituto Nacional de Meteorologia, 2003. 
MAGALHÃES et. al. Populational dynamics of Pseudodiaptomus marshi (Crustacea: Copepoda) in the Caeté estuary (Brazil)

ISLAM, Md.S.; UEDA, H.; TANAKA, M. Spatial and seasonal variations in copepod communities related to turbidity maximum along the Chikugo estuarine gradient in the upper Ariake Bay, Japan. Estuarine, Coastal and Shelf Science, v. 68, p. 113-126, 2006.

KEUTHEN, H. Nahrungsökologische Untersuchungen an ausgewählten Beispielen der Ichthyofauna der Mangrove vor Bragança (Pará, Brasilien). Bremen, 1998. 114f. Tese (Doutorado em Ciências Naturais). Universidade de Bremen.

KIBIRIGE, I.; PERISSINOTTO, R. The zooplankton community of the Mepanjati Estuary, a South African temporarily open/closed system. Estuarine, Coastal and Shelf Science, v. 58, p. 727-741, 2003.

KRUMME, U.; LIANG, T.-H. Tidal-induced changes in a copepod-dominated zooplankton community in a macrotidal mangrove channel in Northern Brazil. Zoological Studies, $v$. 43, n. 2, p. 404-414, 2004.

LAM-HOAI, T.; GUIRAL, D.; ROUGIER, C. Seasonal change of community structure and size spectra of zooplankton in the Kaw River estuary (French Guiana). Estuarine, Coastal and Shelf Science, v. 68, p. 47-61, 2006.

LARA, R.J.; DITTMAR, T. Nutrient dynamics in a mangrove creek (North Brazil) during the dry season. Mangroves and Salt Marshes, v. 3, p. 185-195, 1999.

LUCAS, A.P.O. Variação sazonal do zooplâncton nos estuários dos rios Botafogo e Siriji, litoral norte de Pernambuco - Brasil. Recife, 2006. 77f. Dissertação (Mestrado em Recursos Pesqueiros e Aqüicultura) - Departamento de Pesca. Universidade Federal Rural de Pernambuco.

MADHU, N.V.; JYOTHIBABU, R.; BALACHANDRAN, K.K.; HONEY, U.K.; MARTIN, G.D.; VIJAY, J.G.; SHIYAS, C.A.; GUPTA, G.V.M.; ACHUTHANKUTTY, C.T. Monsoonal impact on planktonic standing stock and abundance in a tropical estuary (Cochin backwaters India). Estuarine, Coastal and Shelf Science, v. 73, p. 54-64, 2007.

MAGALHÃES, A.; COSTA, R.M.; LIANG, T.-H.; PEREIRA, L.C.C.; RIBEIRO, M.J.S. Spatial and temporal distribution in density and biomass of two Pseudodiaptomus species (Copepoda: Calanoida) in the Caeté River Estuary (Amazon region - North of Brazil). Brazilian Journal of Biology, v. 66, n. 2A, p. 421-430, 2006.

MCEWEN, G.F.; JOHNSON, M.W.; FOLSOM, T.R. A statistical analysis of the performance of the Folsom plankton sample splitter, based upon test observations. Archives of Meteorology, Geophysics and Climatology (Ser. A), v. 7, p. 502-527, 1957.

MENEZES, M.; BERGER, U.; WORBES, M. Annual growth rings and long-term growth patterns of mangrove trees from the Bragança peninsula, North Brazil. Wetlands Ecology and Management, v. 11, p. 233-242, 2003.

MCKINNON, A.D.; KLUMPP, D.W. Mangrove zooplankton of North Queensland, Australia. Hydrobiologia, v. 362, p. 127-143, 1998.

MEDEIROS, G.F.; MEDEIROS, L.S.; HENRIQUES, D.M.F.; CARLOS, M.T.L.; FAUSTINO, G.V.B.S.; LOPES, R.M. Current distribution of the exotic copepod Pseudodiaptomus trihamatus Wright, 1937 along the northeastern coast of Brazil. Brazilian Journal of Oceanography, v. 54, n. 4, p. 241-245, 2006.

NASCIMENTO, S.A.; ROCHA, C.E.F. Determinação da composição do zooplâncton em quatro estuários de Sergipe - nordeste do Brasil. Aracaju, 1984. 40 p.

OSORE, M.K.W.; FIERS, F.; DARO, M.H. Copepod composition, abundance and diversity in Makupa Creek, Mombasa, Kenya. Western Indian Ocean Journal of Marine Science, v. 2, n. 1, p. 65-73, 2003.

PARSONS, T.R.; TAKAHASHI, M.; HARGRAVE, B. (Ed.). Biological Oceanographic Processes. $3^{\text {rd }}$ ed Oxford: Pergamon Press, 1984. 330 p. 
PERES, A.C. A comunidade zooplanctônica em um canal de maré no Estuário do Rio Caeté, Bragança (Pará, Brasil). Belém, 1999. 121f. Dissertação (Mestrado em Zoologia) - Departamento de Biologia. Universidade Federal do Pará/Museu Paraense Emílio Goeldi.

REID, J.W. Continental and coastal free-living Copepoda (Crustacea) of Mexico, Central America and the Caribbean region. In: NAVARRO, D.; ROBINSON, J.G. (Ed.). Diversidad Biológica en la Reserva de la Biosfera de Sian Ka'an, Quintana Roo, México. Florida: CIQRO/University of Florida, 1990, p. 175 - 213.

REVIS, N. Preliminary observations on the copepods of Tudor Creek, Mombasa, Kenya. Hydrobiologia, v. 167/168, p. 343-350, 1988.

SCHIPP, G.R.; BOSMANS, J.M.P.; MARSHALL, A.J. A method for hatchery culture of tropical calanoid copepods, Acartia spp. Aquaculture, v. 174, p. 81-88, 1999.

SILVA, T.A.; PARANAGUÁ, M.N.; NEUMANN-LEITÃO, S.; NOGUEIRA-PARANHOS, J.D. Zooplâncton do Estuário do Rio Capibaribe, Recife-PE (Brasil). Trabalhos Oceanográficos da Universidade Federal de Pernambuco, v. 24, p. 79-102, 1996.

SILVA, T.A.; NEUMANN-LEITÃO, S.; SCHWAMBORN, R.; GUSMÃO, L.M.O.; NASCIMENTOVIEIRA, D.A. Diel and seasonal changes in the macrozooplankton community of a tropical estuary in Northeastern Brazil. Revista Brasileira de Zoologia, v. 20, n. 3, p. 439-446, 2003.

SUÁREZ-MORALES, E. Historical biogeography and distribution of the freshwater calanoid copepods (Crustacea: Copepoda) of the Yucatan Peninsula, Mexico. Journal of Biogeography, v. 30, p. 1851-1859, 2003.

THÜLLEN, N.; BERGER, U. A comparative examination of environmental factors at patchy mangrove seedling stands on the peninsula of Bragança, Northern Brazil. Ecotropica, v. 6 , p. 1-12, 2000.

UYE, S.; IWAI, Y.; KASAHARA, S. Growth and production of the inshore marine copepod Pseudodiaptomus marinus in the central part of the Inland Sea of Japan. Marine Biology, v. 73, p. 91-98, 1983.

UYE, S.; SANO, K. Seasonal reproductive biology of the small cyclopoid copepod Oithona davisae in a temperate eutrophic inlet. Marine Ecology Progress Series, v. 118, p. 121-128, 1995.

WALTER, T.C. The zoogeography of genus Pseudodiaptomus (Calanoida: Pseudodiaptomidae). Syllogeus, v. 58, p. 502-508, 1986.

WALTER, C.D. Review of the New World species of Pseudodiaptomus (Copepoda: Calanoida), with a key to the species. Bulletin of Marine Science, v. 45, p. 590-628, 1989.

ZAR, J.H. (Ed.). Biostatistical Analysis. $4^{\text {th }}$ ed New Jersey: Prentice-Hall, 1999. 931 p. 